\title{
ADMINISTRATION OF ISLAMIC LAW AND HUMAN RIGHTS \\ The Basis and Its Trajectory in Malaysia
}

\section{Farid Sufian Shuaib}

International Islamic University Malaysia (IIUM), Malaysia

Email:farid@iium.edu.my

\section{Abstract}

This paper looks at the interplay between the administration of Islamic law in Malaysia in relation to Islamic family law and Islamic criminal law; and buman rights. The paper examines the basis of the administration of Islam in Malaysia in relation to its history and post-independence mandate. It looks at the position of human rights under the Federal Constitution and the position of the administration of Islamic law under the constitutional framework. The research found that entrenching fundamental liberties through the supremacy clause resulted in the prevalence of human rights over freedom of religion. However, this is not consistently arrived at since the constitutional frameworks allows for plurality of laws and exclusion of personal law from the principle of equality.

[artikel ini membahas kelindan antara administrasi bukum islam, bukum keluarga islam, bukum pidana islam, dan HAM di Malaysia. Artikel ini berbasis pada sejarah administrasi Islam di Malaysia sebelum dan sesudah kemerdekaan. Pembahsan lain artikel mengamati posisi HAM di bawah Undang Undang Federal Malaysia dan administrasi bukum Islam dalam kerangka konstitusional. Berdasarkan basil riset menunjukkan dasar kebebasan pada supremasi klausul perundangan yang cenderung lebih utama HAM daripada kebebasan beragama. Meskipun demikian, hal ini tidak selalu konsisten ketika perspektif konstitusi mengikuti pluralitas bukum dan eksklusi bukum personal dari prinsip kesetaraan.] 
Keywords: Islamic law, Malaysia, human rights, constitution, equality

\section{A. Introduction}

Islam plays a significant role in the legal system of Malaysia. The sidelining of Islamic law during the intervention of western imperial powers (involving the Portuguese, Dutch and British) beginning in the $15^{\text {th }}$ century did not cause the end of its influence which revive with the independence of Malaysia in 1957 and continue its ascendancy. Around the same time of the Malaysian independence, the conception of human rights gains currency in the international arena with the proclamation of the Universal Declaration of Human Rights (UDHR) by the United Nations General Assembly in 1948. The decolonisation process and the drafting of the UDHR share the same impetus, namely the World War II - the misery it caused and its ending. The revival and the expansion of Islam role in the administration of justice are for some incongruent with the demand of international human rights values. The intersect between the advancement of the role of Islam in the administration of justice in Malaysia with the increasing importance played by international human rights values is considered in this paper by first looking at the history of the administration of Islamic law.

\section{B. The History of Administration}

Before the arrival of the western colonial powers in the Malay Archipelago in the $15^{\text {th }}$ century, Islamic influence has been widespread in that part of the world. The influence of Islam was not only confined to personal level but extended to the governance and the legal system. Speaking on Malaysia, the early process of Islamisation was interrupted in the $18^{\text {th }}$ century with the arrival of the British in the Malay Peninsula. ${ }^{1}$ The colonial powers, particularly the British, not only exploited the natural resources, but also imposed its own law to better exploit the colonial territories. $^{2}$

1 See Syed Al-Attas Muhammad Naguib, Preliminary Statement on a General Theory of the Islamization of the Malay-Indonesian Archipelago (Kuala Lumpur: Dewan Bahasa dan Pustaka, 1969).

2 P.J. Drake, "The Economic Development of British Malaya to 1914: An Essay in Historiography with Some Questions for Historians”, Journal of Southeast Asian Studies, 
In colonising the Malay states British, had preferred to adopt an indirect rule method. Under this method, British retained the Head of the State of the territories but put in place a British officer as the de facto ruler. ${ }^{3}$ Although the terms of the treaties between British and the Rulers of the Malay States exclude British from interfering matters with regard to Islam and Malay custom, in practice the British had no qualm in interfering in matters of Islamic affairs. Laws were enacted to bureaucratise administration of Islamic affairs. While such legislation could be characterised as modernisation of administration of Islamic affairs, the effect of it was also to pin down the area of administration of Islamic law to mainly personal law matters. ${ }^{4}$ Positivist outlook of the law where enacted laws, in contrast to unwritten law, reign supreme means that the largely uncodified laws of Islam was assigned to the sideline. This reformulation of Shariah is one of the fundamental changes brought by the British imperial power. ${ }^{5}$ Islamic law was framed in English legal reasoning and fossilised in judicial precedent. The result became AngloMuhammadan law. Up until the independence of the Federation of Malaya in 1957, once a territorial law, Islamic was reduced in practice to matters of personal law.

\section{Post Independence Administration}

The nine Rulers who lead the nine Malay states were nine independent and sovereign states. However, in fact, the British and not the Rulers who were in control of the administration of the states through the office of those British Residents posted in each state to give instruction to the Rulers except in matters of Malay adat and religion. In addition, those Malay states were grouped together administratively under what is known as the Federated Malay States (FMS) and the Unfederated Malay States (UFMS). On the basis of this administrative grouping during the vol. 10, no. 2 (1979), pp. 262-90.

${ }^{3}$ Rupert Emerson, Malaysia: A Study in Direct and Indirect Rule (Kuala Lumpur: University of Malaya Press, 1964).

4 William R Roff, "Patterns of Islamization in Malaysia, 1890s-1990s: Exemplars, Institutions, and Vectors", Journal of Islamic Studies, vol. 9, no. 2 (1998), pp. 210-28.

5 M.B. Hooker, "Introduction: Islamic Law in South-East Asia", Australian Journal of Asian Law, vol. 4, no. 3 (2002), pp. 213-31. 
British administration that the independent Malaya was fashioned as a federation. It means that the 9 Malay States agreed to come together to form a federal unit without losing their own identity and retaining some autonomous powers. It is important to take note of this position because one of the autonomous power maintained by the Rulers are their position as the Head of Islam in their respective states.

The Federal Constitution that was enacted on the eve of the independence of the Federation of Malaya encapsulates this understanding by specifically mandating that the Rulers are the Head of Religion of Islam in their respective. Consequently, matters related to Islam are put under the legislative and administrative authority of each state. This point is essential in understanding why each state enact their own laws pertinent to Islam and the federation has no power to legislate the matters related to Islam for the states. ${ }^{6}$

Legislation which was in operation before the Independence continues to be reinforced in the Federation of Malaya. ${ }^{7}$ One of the major legislations remark in relation to Islam is the Administration of Islamic Law enactments. One of the bodies established under the legislation is the Muslim Religious Council or Majlis Agama Islam which continues to be operated after the Independence. The members of the Council are from the top level of State public servants including the State Secretary, State Legal Adviser, State Financial Officer, Mufti, the State Chief Police Officer and those who are learning Islamic law. The Council is the main Islamic bodies since it aids and advises the Rulers on matters of Islam. This, however, does not include the matters partinent to Islamic law and administration of justice since the Mufti and Syariah courts have jurisdiction and power on those matters. ${ }^{8}$ The Council also has the responsibility to promote economic and social development of the Muslim community. ${ }^{9}$

The second main institution under the administration of Islam is Mufti who is appointed by the Ruler whose functions is to aid and advise

6 See "Mamat Bin Daud \& Others v Government of Malaysia", Malayan Law Journal, vol. 1 (1988), p. 119.

7 The Commissioner of Law Malaysia, Federal Constitution, 162.

8 Administration of the Religion of Islam (State of Selangor), sec. 6.

9 Administration of the Religion of Islam (State of Selangor), sec. 7. 
the Ruler in matters of Islamic law. The Mufti is the second tier of chief authority on Islamic law. ${ }^{10}$ In producing legal opinion, Mufti does not work alone, he is assisted by the Fatwa Committee whose members include the State Legal Adviser and person who are well versed in Islamic law. ${ }^{11}$ The issuance of fatwa does not merely be based on the determination of the Mufti, yet research and study are first carried out and discussed in the Fatwa Committee to prepare a fatwa. The prepared fatwa is then brought to the Muslim Religious Council to be recommended to the Ruler to get his assent to publish the fatwa in the government official publication (Garette). The published fatwa is bound for every Muslim in the State except in matters of personal observance as allowed under Islamic law. ${ }^{12}$

The third institution under the administration of Islamic law is Syariah judiciary. ${ }^{13}$ The courts and the judges are established and appointed by the Ruler. It has three-tiers starting with the Syariah Subordinate Court, the Syariah High Court and the Syariah Appeal Court as the apex court. The Syariah courts have criminal jurisdiction over offences against the precepts of the religion of Islam which receive a wide definition as a general command or injunction, direction or a rule of conduct under Islam. ${ }^{14}$ Nevertheless, the sentencing power of the courts does not exceed fine of five thousand Ringgit Malaysia, imprisonment of 5 years and six strokes of light rattan. Cases in the Syariah Subordinate Court and the Syariah High Courts are heard before a single judge. However, in the Syariah Appeal Court, the appeal cases will be heard by a panel of judges.

The provisions that establish the three institutions are the systemisation of existing institutions that were already in place before or during the British intervention in Malaysia. These legislations brought the improvement and uniformity among the States of these institutions, such as the three-tier court system and formation of the Fatwa Committee.

10 Administration of the Religion of Islam (State of Selangor), sec. 45.

${ }^{11}$ Administration of the Religion of Islam (State of Selangor), sec. 46.

12 For a description of the institution of fatwa in Malaysia, see Farid Sufian Shuaib, Tajul Aris Ahmad Bustami, and Mohd Hisham Mohd Kamal, Administration of Islamic Law in Malaysia, 2nd edition (Petaling Jaya: Lexis Nexis, 2010).

13 Administration of the Religion of Islam (State of Selangor), sec. 55.

14 Federal Court, "Sulaiman bin Takrib v Kerajaan Negeri Terengganu (Kerajaan Malaysia, intervener) and other applications", Malayan Law Journal, vol. 6 (2009), pp. 354-84. 
This brings us to the bodies that are responsible in producing these improvement and uniformity. One of such bodies is the Syariah and Civil Law Review Committee that was established in 1988. The committee produced 6 model laws relating to the administration of Islamic law such as Islamic family law, Islamic law of evidence, Islamic criminal procedure, Islamic civil procedure and Islamic criminal offences. Under these model laws, Syariah courts were separated from the Islamic religious department to ensure the independence of the Islamic judiciary. These model laws were then considered by each State legislative body to be enacted as state law. The State legislature consists of the State Legislative Assembly and the Ruler (or the governor for States that to not have a Ruler).

The works of these institutions, namely the Muslim Religious Council, the Mufti and the Syariah courts give impact on the life of Muslims which in turn may have bear on the enjoyment of rights by the population.

\section{The Human Rights Regime under the Federal Constitution}

The Commission entrusted to draft the Malaysian Federal Constitution was of the opinion that the existing law in Malaya at that time would be able to give adequate protection under federal liberties without the need to incorporate a Bill of Rights. ${ }^{15}$ The Commission firmly believed that the supremacy of the constitution and the courts competency to protect those rights would avert any subversion. Nevertheless, the Commission did incorporate in its draft a chapter on fundamental liberties. The chapter provides, among others, right to life, freedom from slavery and freedom of religion.

To entrench these provisions, the Constitution proclaims itself to be supreme and that any law which is inconsistent with the Constitution is void. ${ }^{16}$ For Minister for Home Affairs v Jamaluddin bin Othman, the decision of the Supreme Court in invalidating a preventive detention order under the now repealed Internal Security Act 1960 against a Malay who converted to Christian and allegedly responsible for the conversion of

\footnotetext{
${ }^{15}$ Federation of Malaya Constitutional Commission, Report of the Federation of Malaya Constitutional Commission, Colonial, no. 330 (London: HM Stationery Office, 1957), para. 161.

16 Article of the Federal Constitution.
} 
several Muslims shows the prominence of freedom of religion over national security. ${ }^{17} \mathrm{On}$ the other hand, religious practices are also limited. The Supreme Court agreed that the authority has power to prohibit the wearing of face veil by Muslim women in the civil service on the ground of public order, wearing of which according to the view of a Mufti to be only commendable. ${ }^{18}$

Similarly, the Federal Court (a court that replaced the Supreme Court) allowed the dismissal of 3 primary school children from the school for their failure to abide by the rule of the school that prohibit the wearing of serban (turban) against their protestation that the dismissal is a breach of the freedom to practice their religion. ${ }^{19}$ Similar to the case of civil servant, the Federal Court took into account the fact that wearing of serban is only commendable, not obligatory.

The restrictions on freedom of religion are not confined to Muslims. The Malaysian courts have ruled that some restrictions over non-Muslims are constitutional taking into account the primary position of Islam in the Federal Constitution. In a widely discussed case, the Federal Court ruled that a prohibition by the Ministry of Home Affairs against a Malaysian Catholic weekly publication in using the word "Allah" in its Malay language section as a translation for the Christian God is valid. ${ }^{20}$

Equality is one of the guarantees under the Federal Constitution. Under this guarantee, the constitution prohibits discrimination based on gender, race and religion. Nevertheless, the Constitution does not require similarity of laws for all ethnic or religious groups. ${ }^{21}$ An exception to the right of equality was made for personal laws. At the time of the Independent, there were different laws applicable to different ethnic

17 Supreme Court, "Minister for Home Affairs v. Jamaluddin bin Othman", Malayan Law Journal, vol. 1 (1989).

18 Supreme Court, "Hjh Halimatussaadiah Bte Hj Kamaruddin v Public Services Commission", Malayan Law Journal, vol. 3 (1994).

19 Federal Court, "Meor Atiqulrahman bin Ishak (an infant, by his guardian ad litem Syed Ahmad Johari bin Syed Mohd) v Fatimah Sihi", Malayan Law Journal, vol. 4 (2006).

${ }^{20}$ Federal Court, "Titular Roman Catholic Archbishop of Kuala Lumpur v Menteri Dalam Negeri \& Ors”, Malayan Law Journal, vol. 4 (2014), p. 765.

21 Article 8 of the Federal Constitution. 
groups and different religious adherents. Members of ethnic Chinese for instance were applied rules that allow for polygyny and these particular rules remains applicable to them even if a Chinese is of a Christian faith. A Ceylonese Hindu on the other hand were said to be monogamous.

In other words, the entrenching of the supremacy of the constitution does not mean that ex facie human rights principles trump all other provisions. Due regard is given to plurality of laws and freedom of religious community to administer their affairs. ${ }^{22}$ Even the constitutional provision that provide federal laws prevails over state laws should not be understood only on its veneer meaning. ${ }^{23}$ Federal laws could not defeat a state law that was enacted within the legislative competency of the states. If not, the Law Reform (Marriage and Divorce) Act 1976 could be said as the prevailing law even over Islamic family statutes enacted by states. This is far from the truth. If this is the position taken in Malaysia, it makes it superfluous constitutional provisions that specifically allows for states to establish Syariah courts and to codify Islamic laws. In addition, the Federal Constitution also allows for the creation of the Native Courts by two states in Borneo, namely Sabah and Sarawak that applies native customary law over the natives. Thus, the Constitution envisages three court systems in Malaysia. There would be not only three different laws in the three different court systems since there are more than 60 ethnic groups in Sabah and Sarawak such as Melanaus, Ibans, Bidayuhs, Kadazan-Dusun, Bajau and Murut that may have their own customary laws. Irrespective of the understanding of the "equality before the law", if so derived from the equality principle under the fundamental liberties of the constitution, it certainly does not mean one personal law for all communities in Malaysia.

\section{E. The Interplay between Administration of Islamic Law and Human Rights}

As the Federal Constitution which contains provisions on

${ }^{22}$ For a discussion on legal pluralism, human rights and constitutionalism, see for instance Anicée Van Engeland, "The Balance Between Islamic Law, Customary Law and Human Rights in Islamic Constitutionalism Through the Prism of Legal Pluralism", Cambridge International Law Journal, vol. 3, no. 4 (2014), pp. 1321-48.

23 Article 75 of the Federal Constitution. 
fundamental liberties is the supreme law, every law in Malaysia is subject to the Federal Constitution. This includes laws regulating the administration of Islamic law and codified Islamic law. Thus, codified Islamic laws such as the enactment on mufti and Islamic offences are judged according to the constitutional framework. ${ }^{24}$

Most of the enactments in governing the affairs of Muslims are included in the Administration of Islamic Law enforcement provisions that is provided under each State a Council of Islamic Religious Affairs. The enactments disponse that each Council is responsible to assist and to advise the respective Rulers of the State, and the Council is the chief authority on Islamic matters (except on matters of Islamic law and administration of justice) next to the Ruler. The Council is also involved in the economic and social development of the Muslim community. ${ }^{25}$

The law enactments also followed by the establishment of Syariah Courts that administer Islamic law generally over Muslims in matters of Islamic law. Apart from establishing the courts, it is provided for appointment and qualification of Syariah judges and lawyers. It may for instance requires that Syariah judges and lawyers should be Muslims. ${ }^{26}$ Another set of ratification enacted Islamic offences such as sexual relations outside marriage and eating in public places during fasting month. ${ }^{27}$ The states of Kelantan and Terengganu enacted laws which are labelled as qisas and budud although this remains only in a statute book without implementation. ${ }^{28}$

${ }^{24}$ For a view on the secular element of the Federal Constitution, see Andrew Harding, "Malaysia: Religious Pluralism and the Constitution in a Contested Polity", Middle East Law and Governance, vol. 4, nos. 2-3 (2012), pp. 356-85.

25 For further discussion on the Majlis, see Shuaib, Bustami, and Kamal, Administration of Islamic Law in Malaysia.

26 See for instance Federal Subsidiary Legislation, Peguam Syarie Rules 1993 - P.U. (A) 408/93, sec. 10; Laws of Malaysia, Administration of Islamic Law (Federal Territories) Act 1993, sec. 59. See also Federal Court, "Majlis Agama Islam Wilayah Persekutuan v Victoria Jayaseele Martin and another appeal”, Malayan Law Journal, vol. 2 (2009), p. 309.

27 See for instance Laws of Malaysia, Syariah Criminal Offences (Federal Territories) Act 1997, sec. 15 and 23.

28 State of Terengganu, Shariah Criminal Offence (Hudud And Qisas); Civil Appeal, "Muhamad Juzaili bin Mohd Khamis \& Ors v State Government of Negeri Sembilan \& Ors”, Malayan Law Journal, vol. 3 (2015), p. 513. 
Issues were raised on the compatibility of administration of Islamic law with human rights. The first basic issue is the existence of plurality of laws in particular personal laws, laws that depends on status of an individual - for instance religious and ethnic legal identity. Since Islamic law and Malay custom were the territorial law and the law of the land in the Malay States ${ }^{29}$ should we say the imposed law of English law and laws of other religious and ethnic grouping to be the divergent laws? In discussing plurality of laws, usually Islamic law is seen as the law that diverted from the mainstream. However, the matrimonial law as indicated in the Law Reform (Marriage and Divorce) Act was enacted in 1976 and only enforced in 1982. In contrast, Islamic law and Malay custom were applied and even duly recognised by the colonial judges to become the applicable laws from the $15^{\text {th }}$ century. Thus, the call to have a unitary law and for all to be subjected to the Law Reform (Marriage and Divorce) Act 1976 by certain section of the society probably should rather be a call to return to Islamic law as the territorial law. Of course this was not the intention of those who made the call but on the contrary, the intention was for Islamic law to be negated and the Law Reform (Marriage and Divorce) Act 1976 to reign supreme. On the other hand, if Islamic law is regarded as the applicable law, members of other faiths have the option to choose their own laws and customs in accordance with pluralism under Islamic law. ${ }^{30}$ Thus, in the early Malaysian legal history, non-Muslim communities were allowed to apply their own personal law.

In respect of Shariah offences, a challenge was made to its validity on the basis that the freedom of religion as espoused in the Federal Constitution should mean freedom of Muslims to act contrary to the commandment under Islamic law and to be free from being prosecuted under the Shariah offences. If this argument is accepted, Shariah offences would be practically unenforceable because any Muslim prosecuted under Syariah offence could insist on claiming his religious freedom not to abide by the injunction of his religion and thus could not be prosecuted. The Federal Court observed that under the constitutional framework, States

29 See Liaw Yock Fang, Undang-Undang Melaka (The laws of Melaka) (The Hague: Martinus Nijhoff, 1976).

30 See for instance Abdur Rahman I. Doi, Non-Muslims under Shariáh (Kuala Lumpur: A.S. Noordeen, 1990). 
were given competency to enact Syariah offences and Syariah courts to have jurisdiction and power to hear prosecution and to sentence guilty parties. Thus, to say that freedom of religion means Muslims could be free from being prosecuted in Syariah courts is absurd and would make the Federal Constitution meaningless. ${ }^{31}$

A more direct challenge to constitutionality of a Syariah offence was made in Muhamad Juzaili bin Mohd Khamis \& Ors v State Government of Negeri Sembilan \& Ors. ${ }^{32}$ In this case several Muslim men have made up themselves as women by wearing feminine clothes and applying make up. They were arrested and charged under section 66 of the Syariah Offences Enactment (Negeri Sembilan) 1992 in the Syariah court. The provision makes it as an offence for any male person who in public space wears woman attire or poses as a woman. They went to the civil courts challenging the constitutionality of section 66 as it is inconsistent with, among others, the right to life and the right to equality. ${ }^{33}$ An intermediate appeal court rules that the provision is unconstitutional by being discriminatory and oppressive towards transsexual. However, the final court of appeal reversed the decision on procedural ground. ${ }^{34}$ Thus, on the substantive law, it is a missed opportunity for the Federal Court to provide the final statement on this human rights issue.

Administration of Islamic law in general does not transverse over the non-Muslims. The Federal Constitution also is emphatic that in matters of offences, Shariah courts have jurisdiction only over Muslims. However, as a court of law, the working of administration of Shariah justice involves the process of discovery, evidence collection

31 Civil Appeal, "Muhamad Juzaili bin Mohd Khamis \& Ors v State Government of Negeri Sembilan \& Ors".

32 Civil Appeal, "Muhamad Juzaili bin Mohd Khamis \& Ors v State Government of Negeri Sembilan \& Ors",

33 The right to life under article 5 and the right to equality under article 8 of the Federal Constitution.

${ }^{34}$ For a detailed comment on the Court of Appeal's decision, see Farid Sufian Shuaib, "Isu Perlembagaan dan Hak Asasi Manusia dalam Pentadbiran Keadilan Jenayah Syariah”, Kanun: Jurnal Undang-Undang Malaysia, vol. 27, no. 1 (2015), pp. 33-54. For another decision related to a question on indecency but not a Shariah offence see Federal Court, "Ooi Kean Thong and Another v Public Prosecutor", Malayan Law Journal, vol. 3 (2006), p. 389. 
and enforcement of orders. These processes may directly or indirectly have to do with non-Muslims. Families of a deceased may give evidence as to whether the deceased practices during his life time consistent with practices of a Muslim or a Buddhist in determining the faith of the deceased. ${ }^{35}$ However, for some non-Muslims, even providing evidence to the Syariah courts is abhorrent and is to be considered as infringing on freedom of religion. If Syariah courts are the court of competent jurisdiction on a matter, it is questionable to refuse to give evidence simply on the ground that the person does not belief in laws applied by the courts. There are probably more than a few Muslims and nonMuslims who do not believe in the laws applied by the civil courts. It is certainly unimaginable for such person to be excused from appearing before the civil court. ${ }^{36}$

Restrictions on converting out of Islam under administration of Islamic law are another problematic issue. The law provides that a Muslim continues to be regarded as a Muslim until Syariah courts declare otherwise. One of the purposes of this requirement is to prevent confusion created by irresponsible allegations against a Muslim that he is no longer a Muslim. In Malaysia this has occurred in relation to party political one-upmanship where a political party may accuse members of another political party of being disbelievers because they do not share the same objectives, means and struggle to uphold Islam in Malaysia. ${ }^{37}$ Thus it is an offence to accuse another Muslim of being a non-Muslim. Another purpose is to provide clarity and preventing reckless selfdeclaration of being a non-Muslim in order to avoid responsibility for Syariah offences. This is because if a person is a non-Muslim, Syariah courts have no jurisdiction over him and he could not be charged for Shariah offences such as sex out of wedlock (zina). Some have attempted to avoid prosecution by declaring themselves to be apostates. ${ }^{38}$

35 Mahkamah Tinggi Syariah Negeri Sembilan, "Permohonan Perisytiharan Status Agama Simati Nyonya binti Tahir”, Jurnal Hukum, vol. 21, no. 2 (2006), p. 221.

36 See further Farid Sufian Shuaib, Powers and Jurisdiction of Syariah Courts in Malaysia, 2nd edition (Singapore: Lexis Nexis, 2008).

37 "Mamat Bin Daud \& Others Vs. Government Of Malaysia".

38 Federal Court, "Kamariah bte Ali dan Lain-lain v Kerajaan Negeri Kelantan dan Satu Lagi”, Malayan Law Journal, vol. 1 (2005), p. 197. 
An effect of this requirement is for those who genuinely want to apostate, they have to apply to Shariah courts for a declaration that they no longer a Muslim. Some consider this to be an unnecessary and cumbersome requirement which infringes their freedom to choose their religion. Azalina bte Jailani complained that such requirement infringed upon her freedom of religion. ${ }^{39}$ According to her the statutory declaration that she made declaring herself to be a Christian should suffice for the law to regard her as a Christian. This claim is plausible. However, in Malaysia the faith of a person, particularly the faith as a Muslim have legal and administrative ramification. The personal law of a person including his liability under Shariah offences, his eligibility for affirmative action in education, licences and employment as conferred by the Federal Constitution, his qualification to be a Menteri Besar (Chief Minister) are all hinges directly or indirectly on his status as a Muslim. Thus, it is equally reasonable to have a court of law to determine legally the faith of a person. Since Syariah courts are the courts with expertise for such determination, Syariah courts is the place to go.

Azalina bte Jailani also complained that Syariah courts could very well refuse to grant such a declaration because Syariah judges regard apostasy as a crime. This is the major problem regarding apostasy; the distrust of Syariah courts. Again, if Syariah courts are the courts of competent jurisdiction, it would be problematic if litigants refuse to submit to its jurisdiction. Even with the finding by a commission of inquiry of corruption, "fixing" of judicial appointment and collusion between politicians, business man and judges in the civil courts, it is still implausible for a party to say that they refuse to submit themselves over the jurisdiction of the civil courts solely based on their distrust of the courts. ${ }^{40}$ Similarly, relevant litigants that should appear before Syariah courts should not refuse to do the same based on feeling of distrust. There could be the cases where application for a declaration of apostasy is not readily forthcoming. However, Syariah courts when faced with

39 Federal Court, "Lina Joy v Majlis Agama Islam Wilayah Persekutuan”, Malayan Law Journal, vol. 4 (2007), p. 585.

40 See Jabatan Perdana Menteri. Unit Pemodenan dan Perancangan Tadbiran, Commission of Enquiry on the Video Clip Recording of Images of a Person Purported to be an Advocate and Solicitor Speaking on the Telephone on Matters Regarding the Appointment of Judges (Malaysia: Percetakan Nasional Malaysia, 2000). 
such appeal do grant the request. Thus, the statement that it is practically impossible for every request for apostate to be granted such declaration is wrong. ${ }^{41}$

The above cases show that the language of human rights is well in place in the discourse of the administration of Islamic law not only in public conversation but also in the courts. The courts sometime have made strong decisions but in others could be perceived of side-stepping the issue by relying on procedural ground. ${ }^{42}$ The increasing intensity of the human rights discourse could only mean more cases will be brought to the courts questioning administration of Islamic law in human rights language. This is certainly good for the administrator to be on guard to ensure compliance on the protection of human rights.

\section{F. Globalisation of Human Rights}

The above discussions look at the interplay between the human rights under the Malaysian constitutional framework and the administration of Islamic law. It would be incomplete in this age of globalisation if no consideration is given to international human rights instruments. One such instrument is the Universal Declaration of Human Rights 1948 (UDHR) which came to fruition through a resolution of the General Assembly of the United Nation. ${ }^{43}$ UDHR which is a declaration and not a treaty contains thirty provisions on human rights covering civil

41 For a discussion on apostasy in Malaysia see for instance Mohamed Azam Mohamed Adil, "Law of Apostasy and Freedom of Religion in Malaysia", Asian Journal of Comparative Law, vol. 2, no. 1 (2007).

42 See Farid Sufian Shuaib, "Constitutional restatement of parallel jurisdiction between civil courts and Syariah courts in Malaysia: Twenty years on (1988-2008)", Malayan Law Journal, vol. 5 (2008), pp. xxxiii-l.

43 Resolution of the General Assembly 217A. See also. Mohd Hisham Mohd Kamal, "Application of International Human Rights Law in Malaysia", in Human Rights Law: International, Malaysian, and Islamic Perspectives, ed. by Abdul Ghafur Hamid and Khin Maung Sein (Petaling Jaya: Sweet and Maxwell Asia, 2012), pp. 279-92; Mashood A. Baderin, "A Macroscopic Analysis of the Practice of Muslim State Parties to International Human Rights Treaties: Conflict or Congruence?", Human Rights Law Review, vol. 1, no. 2 (2001), pp. 265-303; Abdullahi Ahmed An-Na'im, "Islamic Law, International Relations, and Human Rights: Challenge and Response", Cornell International Law Journal, vol. 20, no. 2 (1987), pp. 317-35. 
and political rights, and economic, social and cultural rights. ${ }^{44}$

A question has been raised in the Malaysian courts on whether UDHR is part of Malaysian law. The Malaysian courts have given mix messages in this regard where one may find cases that answered the question in the affirmative and in negative response. ${ }^{45}$ As a resolution that contains the basic principles of international human rights, UDHR should be given some regard. However, the Federal Court as the apex court decided that since Malaysia subscribes to the principle of dualism where international law is not incorporated directly to the municipal law, ${ }^{46}$ the absence of any transformation act to incorporate UDHR into Malaysian law, means that the Malaysian courts are not bound by UDHR. ${ }^{47}$

Malaysia has indeed ratified two treaties related to human rights namely the Convention on the Elimination of All Discrimination Against Women 1979 (CEDAW) on the $4^{\text {th }}$ August 1995 with some reservations and the Child Rights Convention 1989 (CRC) on the $19^{\text {th }}$ March 1995. The country has enacted Child Act 2001 to conform and to transform the CRC into Malaysian law. With regard to CEDAW, Malaysia amended article 8 of the Federal Constitution to include "gender" as one of the grounds that cannot be used for discrimination and amended other laws to ensure gender equality such as right to receive accrued pension by a widow (of a public servant) who remarried.

In ratifying CEDAW, Malaysia had, from the beginning, made declaration that the country's accession is subject to the understanding

44 On the question of globalisation and Islamic law in Malaysia, see Farid Sufian Shuaib, "Kesan Globalisasi terhadap Undang-Undang Islam di Malaysia”, Kanun: Jurnal Undang-Undang Malaysia, vol. 29, no. 2 (2017), pp. 15-35.

45 LRC, "Suzana bt Md Aris v DSP Ishak bin Hussain \& Yang Lain”, Malayan Law Journal, vol. 1 (2011), p. 107; LRC, "Indira Gandhi a/p Mutho v. Pengarah Jabatan Agama Islam Perak \& Ors", Malayan Law Journal, vol. 5 (2013), p. 552; LRC, "Merdeka University Berhad lwn Government of Malaysia”, Malayan Law Journal, vol. 2 (1981), p. 356; LRC, "Pathmanathan a/1 Krishnan (dikenali juga sebagai Muhammad Riduan bin Abdullah) lwn Indira Gandhi a/p Mutho dan Rayuan Yang Lain", Malayan Law Journal, vol. 4 (2016), p. 455.

46 See for instance Ratno Lukito, "Segitiga Hukum Internasional, Municipal dan Islam: Memahami Kompetisi, Interaksi dan Resolusi Hukum di Malaysia", Asy-Syir'ah, vol. 49, no. 1 (2015), pp. 161-91.

47 "Mohamad Ezam bin Mohd Noor lwn Ketua Polis Negara", Malayan Law Journal, vol. 4 (2002), p. 449. 
that provisions of CEDAW are not contrary to Islamic law and the Federal Constitution. ${ }^{48}$ This declarative interpretation by Malaysia is in accordance with the Vienna Convention that allows for states to declare as to the meaning and the extent to which a state accept the effect of the treaty ${ }^{49}$ For instance, CEDAW provides for women to have the right to choose a partner for marriage..$^{50}$ Malaysian law, on the other hand, limited the choice for Muslim women to Muslim men. ${ }^{51}$ Similarly, there is also the need for wali that may be regarded as restricting the freedom to marry for Muslim women.

Additionally, if we consider the status of any international instrument, even a ratified treaty, the Malaysian legislature need to transform the international law into domestic law for it to be enforceable in a court of law in Malaysia. Similar to the position of UDHR that has been discussed above, there are mixed decisions produced by the courts with regard to the enforcement of CEDAW. In support of gender equality and commitment given by the government at the international level, the High Court proclaims that it is the duty of the court to consider that CEDAW has legal effect in the Malaysian courts. ${ }^{52}$ However, the Court of Appeal reaffirmed the transformation doctrine where ratification or accession is not adequate to enforce a treaty at the domestic level..$^{53}$ The legislature needs to act on the decision of the executive.

However, this is not the end of the matter in dealing with international treaties. Recent human right treaties in particular have most of the time included monitoring mechanism in its framework. The CEDAW Committee which consist of independent experts is responsible

48 Reservations to CEDAW, http://www:un.org/womenwatch/daw/cedaw/ reservations-country.htm. The remaining reservation cover articles $9(2), 16(a), 16(c)$, 16(f) and 16(g).

49 Abdul Ghafur Hamid, "Reservations to CEDAW and the implementation of Islamic family law: issues and challenges", Malaysian Journal on Human Rights, vol. 3 , no. 1 (2009), pp. 69-94.

50 Article 16 of CEDAW.

51 Laws of Malaysia, Islamic Family Law (Federal Territory) Act 1984.

52 Federal Court, "Noorfadilla bt Ahmad Saikin v Chayed bin Basirun \& Ors", Malayan Law Journal, vol. 1 (2012), pp. 832-47.

53 Court of Appeal, "AirAsia Bhd v Rafizah Shima bt Mohamed Aris”, Malayan Law Journal, vol. 5 (2014), p. 318. 
in monitoring the compliance of the convention. ${ }^{54}$ Member states of CEDAW have to submit reports to the Committee on the steps taken in compliance with the convention. Although technically the Committee has no power to enforce its view, it still could assert political pressure over compliance with its recommendation to the General Assembly of the United Nation. Recently, the Malaysian government delegation was questioned by the CEDAW Committee in Geneva. ${ }^{55}$ In this regard the issue of universalism in human rights needs to be considered.

\section{G. Universality of Human Rights and Universalism in Human Rights}

Mashood Baderin observed that distinction must be made between universality of human rights and universalism in human rights. ${ }^{56}$ Universality of human rights refers to the universal quality or global acceptance of the human rights idea, while "universalism in" human rights refers to the interpretation and application of the human rights idea. Universality of human rights has been achieved by the adoption of UDHR in 1948 and acceptance of the language of human rights in international relations.

On the other hand, universalism in human rights has not been achieved by the absence of consensus of a common "universal value" for the interpretation and application of human rights law. Cultural relativist argument is still being heard in the human rights discourse. Take for instance, the headscarf ban in Europe. The European Court of Justice in Luxemburg decided in March 2017 that companies can ban employee from wearing Islamic headscarves at work and this does not constitute discrimination or breach of freedom of religion. The

54 Article 17 of CEDAW.

55 Treaty bodies Sessions, https://tbinternet.ohchr.org/_layouts/ treatybodyexternal/SessionDetails1.aspx?SessionID=1157\&Lang=en; Yiswaree Palansamy, "Why choose fatwa over civil laws? UN committee asks Putrajaya", malaymail. com (21 Feb 2018), https://www.malaymail.com/news/malaysia/2018/02/21/whychoose-fatwa-over-civil-laws-un-committee-asks-putrajaya/1582151, accessed 20 Aug 2018.

56 Mashood A. Baderin, "Dialogue Among Civilisations as a Paradigm for Achieving Universalism in International Human Rights a Case Study with Islamic Law", Asia-Pacific Journal on Human Rights and the Law, vol. 2, no. 2 (2001), pp. 1-41. 
basis of the judgment is to enable companies and businesses to show religious and political neutrality. This has to be read together with other judgements that support policies which are in line with the culture and way of life of the European countries which is secular. Certainly the judgement of the European Court of Justice is not shared by Malaysian where the wearing of turban by the Sikhs is regarded as manifestation of their religious freedom. Hindus in Malaysia have also indicated that they should be able to wear the sign on their forehead.

This relativist approach is also taken in reading the German constitution by upholding the prohibition of questioning the holocaust against the Jews in World War II even in academic works. ${ }^{57}$ Such restrictions against free speech are not acceptable in the United States of America.

It is not the purpose of this article to debate the correctness or desirability of the judgment of the highest supranational court in Europe or the European state courts. What is to be highlighted is that for those European supranational and state courts, the protection of the culture, the way of life, political ideology and majoritarian sensitivities are legitimate grounds in moulding their application of human rights, including the right of equality and freedom of religion. Thus, the courts in other countries and regions should also be given the space and the margin of appreciation in shaping the application of human rights in their countries.

\section{H. Concluding Remarks}

The place of Islam in the public life, particularly in the administration of justice, will continue to be debated in Malaysia. The basic document that establishes the federation of Malaysia in the form the Federal Constitution clearly provides for Islam to have a place in the public life, including in matters of administration of justice and Muslim affairs. The Constitution allows for codification of Islamic law and establishment of Shariah courts. What is left to be debated is the purview

${ }^{57}$ Ronald Krotoszynski, "Free Speech Paternalism and Free Speech Exceptionalism: Pervasive Distrust of Government and the Contemporary First Amendment", SSRN Scholarly Paper, no. ID 2655700 (Rochester, NY: Social Science Research Network, 2015); Michel Rosenfeld, "Hate Speech in Constitutional Jurisprudence: A Comparative Analysis”, SSRN Scholarly Paper, no. ID 265939 (Rochester, NY: Social Science Research Network, 2001). 
of such enactment over the life of Muslims and the aspired result from the interplay between human rights and administration of Islamic law.

Other Muslim countries also confront the intertwined issues of human rights and the application of Islamic law. Although not all states that have majority Muslims population place administration of Islamic law in the mainstream as in Malaysia, the states still has to face the issue of Islam and human rights. ${ }^{58}$ In Indonesia for instance, Islamic family law is applicable for Muslims. ${ }^{59}$ Some issues, such as interfaith marriages and dissolution of marriages on the ground of apostasy, invite the issue of human rights. ${ }^{60}$ More issues arise in the special province of Aceh where the special province establishes Syariah courts to administer Islamic law including Shariah offences. ${ }^{61}$ Observing what transpired in Muslim countries, some opined that the legislature and the judiciary have the ability to mould Islamic law to be consistent with international human rights law. ${ }^{62}$ Nevertheless, as what transpired in Malaysia, the legislature and the judiciary of each of the countries should be given space to shape their own law.

58 See for instance Indonesia as the Pancasila-based state; Turkish as the selfproclaimed secular state; and Algerian, Jordanian and Yemeni constitution proclaims Islam as the religion of the state. See further Nisrine Abiad, Sharia, Muslim States and International Human Rights Treaty Obligations: A Comparative Study (London: British Institute of International and Comparative Law, 2008).

59 Euis Nurlaelawati, "Muslim Women in Indonesian Religious Courts: Reform, Strategies, and Pronouncement of Divorce”, Islamic Law and Society, vol. 20, no. 3 (2013), pp. 242-71.

${ }^{60}$ Euis Nurlaelawati, "For the Sake of Protecting Religion: Apostasy and its Judicial Impact on Muslim's Marital Life in Indonesia", Journal of Indonesian Islam, vol. 10, no. 1 (2016), pp. 89-112.

61 Asma T. Uddin, "Religious Freedom Implications of Sharia Implementation in Aceh, Indonesia", University of St. Thomas Law Journal, vol. 7, no. 3 (2010), pp. 603-48.

62 Abiad, Sharia, Muslim States and International Human Rights Treaty Obligations: A Comparative Study, p. 173; The Netherlands Scientific Council for Government Policy, Dynamism in Islamic Activism: Reference Points for Democratization and Human Rights (Amsterdam: Amsterdam University Press, 2006), p. 140. 


\section{BIBLIOGRAPHY}

Abiad, Nisrine, Sharia, Muslim States and International Human Rights Treaty Obligations: A Comparative Study, London: British Institute of International and Comparative Law, 2008.

Administration of the Religion of Islam (State of Selangor).

Al-Attas, Syed Muhammad Naguib, Preliminary Statement on a General Theory of the Islamization of the Malay-Indonesian Archipelago, Kuala Lumpur: Dewan Bahasa dan Pustaka, 1969.

An-Na'im, Abdullahi Ahmed, "Islamic Law, International Relations, and Human Rights: Challenge and Response", Cornell International Law Journal, vol. 20, no. 2, 1987, pp. 317-35.

Baderin, Mashood A., "A Macroscopic Analysis of the Practice of Muslim State Parties to International Human Rights Treaties: Conflict or Congruence?", Human Rights Law Review, vol. 1, no. 2, 2001, pp. 265-303.

----, "Dialogue Among Civilisations as a Paradigm for Achieving Universalism in International Human Rights a Case Study with Islamic Law", Asia-Pacific Journal on Human Rights and the Law, vol. 2, no. 2, 2001, pp. 1-41 [http://dx.doi.org/10.1163/15718150140 0649008].

Civil Appeal, "Muhamad Juzaili bin Mohd Khamis \& Ors v State Government of Negeri Sembilan \& Ors", Malayan Law Journal, vol. 3, 2015, p. 513.

Commission, Federation of Malaya Constitutional, Report of the Federation of Malaya Constitutional Commission, Colonial, no. 330, London: HM Stationery Office, 1957.

Court of Appeal, "AirAsia Bhd v Rafizah Shima bt Mohamed Aris", Malayan Law Journal, vol. 5, 2014, p. 318.

Doi, Abdur Rahman I., Non-Muslims under Shariáh, Kuala Lumpur: A.S. Noordeen, 1990.

Drake, P.J., "The Economic Development of British Malaya to 1914: An Essay in Historiography with Some Questions for Historians", Journal of Southeast Asian Studies, vol. 10, no. 2, 1979, pp. 262-90 
[http://dx.doi.org/10.1017/S0022463400014247].

Emerson, Rupert, Malaysia: A Study in Direct and Indirect Rule, Kuala Lumpur: University of Malaya Press, 1964.

Engeland, Anicée Van, "The Balance Between Islamic Law, Customary Law and Human Rights in Islamic Constitutionalism Through the Prism of Legal Pluralism", Cambridge International Law Journal, vol. 3, no. 4, 2014, pp. 1321-48 [http://dx.doi.org/10.7574/ cjicl.03.04.250].

Fang, Liaw Yock, Undang-Undang Melaka (The laws of Melaka), The Hague: Martinus Nijhoff, 1976.

Federal Court, "Kamariah bte Ali dan Lain-lain v Kerajaan Negeri Kelantan dan Satu Lagi”, Malayan Law Journal, vol. 1, 2005, p. 197.

----, "Meor Atiqulrahman bin Ishak (an infant, by his guardian ad litem Syed Ahmad Johari bin Syed Mohd) v Fatimah Sihi", Malayan Law Journal, vol. 4, 2006.

----, "Ooi Kean Thong and Another v Public Prosecutor", Malayan Law Journal, vol. 3, 2006, p. 389.

----, "Lina Joy v Majlis Agama Islam Wilayah Persekutuan", Malayan Law Journal, vol. 4, 2007, p. 585.

----, "Sulaiman bin Takrib v Kerajaan Negeri Terengganu (Kerajaan Malaysia, intervener) and other applications", Malayan Law Journal, vol. 6, 2009, pp. 354-84.

----, "Majlis Agama Islam Wilayah Persekutuan v Victoria Jayaseele Martin and another appeal", Malayan Law Journal, vol. 2, 2009, p. 309.

----, "Noorfadilla bt Ahmad Saikin v Chayed bin Basirun \& Ors", Malayan Law Journal, vol. 1, 2012, pp. 832-47.

----, "Titular Roman Catholic Archbishop of Kuala Lumpur v Menteri Dalam Negeri \& Ors", Malayan Law Journal, vol. 4, 2014, p. 765.

Federal Subsidiary Legislation, Peguam Syarie Rules 1993 - P.U. (A) 408/93.

Hamid, Abdul Ghafur, "Reservations to CEDAW and the implementation of Islamic family law: issues and challenges", Malaysian Journal on Human Rights, vol. 3, no. 1, 2009, pp. 69-94.

Harding, Andrew, "Malaysia: Religious Pluralism and the Constitution in 
a Contested Polity", Middle East Law and Governance, vol. 4, nos. 2-3, 2012, pp. 356-85 [http:// dx.doi.org/10.1163/18763375-00403007]. Hooker, M.B., "Introduction: Islamic Law in South-East Asia", Australian Journal of Asian Law, vol. 4, no. 3, 2002, p. 213.

Jabatan Perdana Menteri. Unit Pemodenan dan Perancangan Tadbiran, Commission of Enquiry on the Video Clip Recording of Images of a Person Purported to be an Advocate and Solicitor Speaking on the Telephone on Matters Regarding the Appointment of Judges, Malaysia: Percetakan Nasional Malaysia, 2000.

Kamal, Mohd Hisham Mohd, "Application of International Human Rights Law in Malaysia", in Human Rights Law: International, Malaysian, and Islamic Perspectives, ed. by Abdul Ghafur Hamid and Khin Maung Sein, Petaling Jaya: Sweet and Maxwell Asia, 2012, pp. 279-92.

Krotoszynski, Ronald, "Free Speech Paternalism and Free Speech Exceptionalism: Pervasive Distrust of Government and the Contemporary First Amendment", SSRN Scholarly Paper, no. ID 2655700, Rochester, NY: Social Science Research Network, 2015.

Laws of Malaysia, Islamic Family Law (Federal Territory) Act 1984.

----, Administration of Islamic Law (Federal Territories) Act 1993.

----, Syariah Criminal Offences (Federal Territories) Act 1997.

LRC, "Merdeka University Berhad v Government of Malaysia", Malayan Law Journal, vol. 2, 1981, p. 356.

----, "Suzana bt Md Aris v DSP Ishak bin Hussain \& Yang Lain", Malayan Law Journal, vol. 1, 2011, p. 107.

----, "Indira Gandhi a/p Mutho v Pengarah Jabatan Agama Islam Perak \& Ors", Malayan Law Journal, vol. 5, 2013, p. 552.

----, "Pathmanathan a/1 Krishnan (dikenali juga sebagai Muhammad Riduan bin Abdullah) lwn Indira Gandhi a/p Mutho dan Rayuan Yang Lain”, Malayan Law Journal, vol. 4, 2016, p. 455.

Lukito, Ratno, "Segitiga Hukum Internasional, Municipal dan Islam: Memahami Kompetisi, Interaksi dan Resolusi Hukum di Malaysia", Asy-Syir'ah, vol. 49, no. 1, 2015, pp. 161-91 [http://dx.doi. org/10.14421/asy-syir'ah.2015.\%x].

Mahkamah Tinggi Syariah Negeri Sembilan, "Permohonan Perisytiharan 
Status Agama Simati Nyonya binti Tahir", Jurnal Hukum, vol. 21, no. 2, 2006.

"Mamat Bin Daud \& Others v Government of Malaysia", Malayan Law Journal, vol. 1, 1988, p. 119.

"Mohamad Ezam bin Mohd Noor v Ketua Polis Negara", Malayan Law Journal, vol. 4, 2002, p. 449.

Mohamed Adil, Mohamed Azam, "Law of Apostasy and Freedom of Religion in Malaysia", Asian Journal of Comparative Law, vol. 2, no. 1, 2007 [http://dx.doi.org/10.2202/1932-0205.1060].

Nurlaelawati, Euis, "Muslim Women in Indonesian Religious Courts: Reform, Strategies, and Pronouncement of Divorce", Islamic Law and Society, vol. 20, no. 3, 2013, pp. 242-71.

----, "For the Sake of Protecting Religion: Apostasy and its Judicial Impact on Muslim's Marital Life in Indonesia", Journal of Indonesian Islam, vol. 10, no. 1, 2016, pp. 89-112 [http://dx.doi.org/10.15642/ JIIS.2016.10.1.89-112].

Palansamy, Yiswaree, "Why choose fatwa over civil laws? UN committee asks Putrajaya", malaymail.com, 21 Feb 2018, https://www.malaymail. $\mathrm{com} /$ news/malaysia/2018/02/21/why-choose-fatwa-over-civillaws-un-committee-asks-putrajaya/1582151, accessed 20 Aug 2018.

Reservations to CEDAW, http://www:un.org/womenwatch/daw/cedaw/ reservations-country.htm.

Roff, William R., "Patterns of Islamization in Malaysia, 1890s-1990s: Exemplars, Institutions, and Vectors", Journal of Islamic Studies, vol. 9, no. 2, 1998, pp. 210-28.

Rosenfeld, Michel, "Hate Speech in Constitutional Jurisprudence: A Comparative Analysis", SSRN Scholarly Paper, no. ID 265939, Rochester, NY: Social Science Research Network, 2001.

Shuaib, Farid Sufian, Powers and Jurisdiction of Syariah Courts in Malaysia, 2nd edition, Singapore: Lexis Nexis, 2008.

----, "Constitutional restatement of parallel jurisdiction between civil courts and Syariah courts in Malaysia: Twenty years on (1988-2008)", Malayan Law Journal, vol. 5, 2008, pp. xxxiii-1.

----, "Isu Perlembagaan dan Hak Asasi Manusia dalam Pentadbiran 
Keadilan Jenayah Syariah", Kanun: Jurnal Undang-Undang Malaysia, vol. 27, no. 1, 2015, pp. 33-54.

----, "Kesan Globalisasi terhadap Undang-Undang Islam di Malaysia", Kanun: Jurnal Undang-Undang Malaysia, vol. 29, no. 2, 2017, pp. 15-35.

Shuaib, Farid Sufian, Tajul Aris Ahmad Bustami, and Mohd Hisham

Mohd Kamal, Administration of Islamic Law in Malaysia, 2nd edition, Petaling Jaya: Lexis Nexis, 2010.

State of Terengganu, Shariah Criminal Offence (Hudud and Qisas).

Supreme Court, "Minister for Home Affairs v Jamaluddin bin Othman", Malayan Law Journal, vol. 1, 1989.

----, "Hjh Halimatussaadiah Bte Hj Kamaruddin v Public Services Commission", Malayan Law Journal, vol. 3, 1994.

The Commissioner of Law Malaysia, Federal Constitution, 162.

The Netherlands Scientific Council for Government Policy, Dynamism in Islamic Activism: Reference Points for Democratization and Human Rights, Amsterdam: Amsterdam University Press, 2006.

Treaty Bodies Sessions, https://tbinternet.ohchr. org/_layouts/treatybodyexternal/SessionDetails 1. aspx?SessionID=1157\&Lang=en.

Uddin, Asma T., "Religious Freedom Implications of Sharia Implementation in Aceh, Indonesia", University of St. Thomas Law Journal, vol. 7, no. 3, 2010, pp. 603-48. 